\title{
Impact of Covid-19 on Socio-Economics and the Global Justice System
}

\author{
Nisal Pathiraja, Kiyara de Silva \\ University of London
}

\begin{abstract}
As the end of 2019 drew nearer, the world eagerly awaited the New Year with high expectations, ranging from individual aspirations such as travelling and career related goals, to more general plans such as those pertaining to technology, the economy and society as a whole. These were soon dissipated with the occurrence of various unpleasant events including environmental tragedies and political unrest. The unprecedented outbreak of this virus has led to governments around the world implementing emergency protocols such as quarantine policies and public awareness programs.
\end{abstract}

This research focuses on how COVID-19 has made a great impact on world society and its' functioning. Focus will be given to the origins of the virus and how the pandemic has made certain changes to the socio-economic aspect. It has now come to a point where everyone has to live with the virus until it is completely eradicated, this completion cannot be foretold. Therefore, this research will examine on how day to day life style has changed due to this pandemic and the new trends that have emerged from it. Governments are at the center of control; their actions need to be discussed as not all governments respond the same way. Finally, a detailed analysis will be given in relation to the global justice system on how the pandemic has transformed the traditional procedures. Furthermore, emphasis will be given on certain guidelines and recommendations implemented by various states and institutions in the modification and adaptation of the courts.

\section{INTRODUCTION}

\section{The Beginning of a Pandemic}

$\mathrm{O}^{\mathrm{n}}$ $\mathrm{n}$ the 8th of December 2019, the Chinese government reported the first official case related to the novel coronavirus, also known as COVID-19, from the city of Wuhan. ${ }^{1}$ On the 31 st of December, the World Health Organization (WHO) was alerted about unusual cases of pneumonia. These initial recorded batches of cases would be the first of more than 45 million cases, a count which continues to rapidly increase daily. The virus is thought to have originated in an illegal seafood market and scientists have pointed out that the consumption of either bats or snakes are possible sources to the origin of this virus. ${ }^{2}$ Results have

\footnotetext{
1 Helen Davidson, 'First Covid 19 case happened in November, China government reports show' The Guardian (Hong Kong, 13 March 2020) <https://www.theguardian.com/world/2020/mar/13/first-covid-19-case-

happened-in-november-china-government-records-show-report >

${ }^{2}$ David M. Morens and others, The Origin of COVID-19 and Why It Matters, 22nd July 2020

< https://www.ncbi.nlm.nih.gov/pmc/articles/PMC7470595/ >
}

shown that this virus spreads between people, mainly through respiratory droplets of an infected person-

Coronaviruses are a family of viruses that cause illness in humans and animals, of which several types have been identified thus far and are responsible for SARS, MERS and COVID-19 epidemics. ${ }^{3}$ They consist of relatively simple structures which are spherical and coated with spikes of protein which help the virus bind to and infect healthy cells. These spikes can be used in potential coronavirus vaccines to prompt the body to produce antibodies against this new virus. Detergents and alcohols tend to destroy this membrane hence, the reason why the use of soap, water and hand sanitizers are encouraged. Common symptoms include fever, cough, fatigue and respiratory distress. Severe acute respiratory syndrome coronavirus 2 (SARS-CoV-2) is the virus responsible for the current outbreak of the coronavirus disease. It is closely related to a group of SARS-CoVs commonly found in humans, bats, pangolins and civets. ${ }^{4}$ Viruses that cause chickenpox and smallpox are made of DNA, while coronaviruses are composed of RNA which contain small genomes that are subjected to constant change. These genomes cause the virus to mutate, as a result of which no one is immune to it. Meaning that it will potentially infect a very large number of people in a very short period of time. ${ }^{5}$ Studies show that even though the incubation period of the virus is currently unknown, symptoms could appear between 2 to 14 days following exposure to the virus with possible infections during this period. ${ }^{6}$

The H1N1 pandemic of 2009 was the most recent pandemic before the novel coronavirus causing respiratory infections in humans and was commonly referred to as 'swine flu'? According to the United States Department of Health and Human Services, the manner in which the 2009 pandemic was handled is generally considered to be relatively successful.

\footnotetext{
Lauren M, Sauer, M.S. 'What is Coronavirus?' (John Hopkins Medicine, 5 November 2020) < https://www.hopkinsmedicine.org/health/conditions-anddiseases/coronavirus >

4 'What is coronavirus? The different types of coronaviruses' (UK Research and Innovation, 7 July 2020)

https://coronavirusexplained.ukri.org/en/article/cad0003/\#ref4 >

5 Stephanie Pappas, 'A new coronavirus mutation is taking over the world. Here's what that means' (Live Science, 10 July 2020) < https://www.livescience.com/new-coronavirus-mutation-explained.html > ${ }^{6}$ Ibid

${ }^{7}$ Mayo Clinic Staff, 'H1N1 flu (swine flu), (Mayo Clinic, 20 October 2020) < https://www.mayoclinic.org/diseases-conditions/swine-flu/symptomscauses/syc-20378103 >
} 
The Centre for Disease Control indicated that this success was attributable to the fact that the authorities were able to quickly communicate scientifically sound information regarding the virus to policy makers, local stakeholders and the community, allowing parties to take timely strategic decisions to tackle the H1N1 pandemic. In comparison to the previous pandemic, COVID-19 has proven to be more challenging when developing and executing an appropriate response. Compared to the novel coronavirus, the $\mathrm{H} 1 \mathrm{~N} 1$ virus was less contagious and had a very slow growth rate, allowing the medical services to control the virus effectively. Authorities were able to develop a vaccination which was made available to the public within a few months after the WHO declared H1N1 as a global pandemic. ${ }^{8}$ The unfamiliarity of the present day virus has caused confusion amongst authorities regarding the scope of the virus and possible measures of tackling it.

\section{IMPACT ON SOCIO-ECONOMICS}

These pandemics have taken many lives, causing severe economic and social downfall. However, every time a pandemic occurred, the world managed to adapt and overcome the challenges that they faced. Regardless of the measures taken by the world society, pandemics tend to resurface. The novel coronavirus has caused significant economic and social downfalls such as job losses, cuts in income, reductions in general welfare of the population and a gradual increase in poverty. ${ }^{9}$ This has damaged many industries in the world, triggering what is possibly the worst economic crisis since the Great Depression of the late 1930's. The economic crisis of the late 1930's was a result of World War One and the Spanish Flu of 1920. During the First World War, many diseases and famines spread through European countries such as France, Netherlands, Belgium and Germany due to trench warfare, resulting in the collapse of their economies. In the post-world war era, while some countries were recovering from one of the most devastating wars in human history, the world was struck by a new pandemic called the Spanish Flu. This pandemic was caused by the H1N1 Influenza (A) Virus which lasted from 1918 to 1920 and caused the loss of 100 million lives. Even though this pandemic caused major economic disruptions in some countries, it was not a main contributing factor to The Great Depression. The main cause of The Great Depression was the United States stock market crash, also known as the Wall Street Crash, of October $29^{\text {th }} 1929$. This crash had a domino effect on the world economy, causing a major decline of $15 \%$ in the global Gross Domestic Product (GDP). ${ }^{10}$ Comparatively, the novel coronavirus pandemic has been the direct cause of the negative effect on the global economy.

\footnotetext{
${ }^{8} 2009$ H1N1 Pandemic, Centers for Disease Control and Prevention (2018) < https://www.cdc.gov/flu/pandemic-resources/2009-h1n1-pandemic.html > 9 'UNDP COVID 19: Socio-economic Impact', (UNDP, June 2020) < https://www.undp.org/content/undp/en/home/coronavirus/socio-economicimpact-of-covid-19.html >

10 Vincenzo D'Apice, Giovanni Ferri, The Great Depression of the 1930s (2010) < https://link.springer.com/chapter/10.1057\%2F9780230297111_7 >
}

\subsection{The global economy}

Economists have estimated that most major economies will experience a loss of $2.4 \%$ value from their GDPs. Economic turmoil associated with the COVID-19 pandemic caused the global stock market to fall on the 24th of February 2020, showing the largest, single-week decline since the financial crisis of 2008. It has also been predicted that global growth could shrink by almost $8 \%$ by the end of this year. ${ }^{11}$ According to the World Bank, the current recession caused by the COVID-19 pandemic has 'the fastest, steepest downgrades in consensus growth projections among all global recessions since 1990'. ${ }^{12}$ This economic turmoil was supplemented by the fear of a long term lockdown leading to an unprecedented period of panic buying. Which caused temporary shortages in food and other essential items, as producers were unable to meet the ever increasing demand of consumers, leading to an escalation in price. Subsequently, due to the global recession, many manufacturing organizations have declared bankruptcy or are under heavy debt. ${ }^{13}$

\subsection{War amidst the pandemic}

The impact of COVID-19 in certain low-income economies has caused damage to internal healthcare systems, exacerbating the slowing potential growth and productivity. Taking Yemen as an example, the UNDP has mentioned that 24 million out of 30 million people in Yemen depend on humanitarian assistance. Most of the population is seriously malnourished and have been weakened by diseases such as dengue and malaria. According to Al Jazeera, the Yemeni healthcare system has been all but decimated by war, with many healthcare facilities destroyed by airstrikes and shellings, a situation worsen by the COVID-19 pandemic. $^{14}$ Even though the United Nations and 16 other humanitarian partners lodged an emergency appeal to gather $\$ 2$ billion to fight coronavirus in Yemen, some UN programs in Yemen are at risk of running out of money due to the worsening situation in the country and the lack of international support. ${ }^{15}$

In contrast, high income countries such as the USA have companies working to develop an effective vaccine. However, this has proved to be difficult due to the high mutation level of the virus. The coronavirus in the US caused a significant

\footnotetext{
${ }^{11}$ Statista Research Department, 'Impact of the coronavirus pandemic on the global economy - Statistics and Facts' (Statista, 20 November 2020) < https://www.statista.com/topics/6139/covid-19-impact-on-the-globaleconomy/ >

12 'The Global Economic Outlook During the COVID 19 Pandemic: A Changed World' ( The World Bank, 8 June 2020) < https://www.worldbank.org/en/news/feature/2020/06/08/the-globaleconomic-outlook-during-the-covid-19-pandemic-a-changed-world >

${ }^{13}$ S. M. Yasir Arafat and others, Responsible Factors of Panic Buying: An Observation from Online Media Reports ( $5^{\text {th }}$ November 2020) < https://www.frontiersin.org/articles/10.3389/fpubh.2020.603894/full >

${ }^{14}$ Yemen's health system 'has collapsed' as coronavirus spreads (May 2020) $<\quad$ https://www.aljazeera.com/news/2020/5/22/yemens-health-system-hascollapsed-as-coronavirus-spreads-un >

${ }^{15}$ Afrah Nasser, War and COVID-19 in Yemen, Istituto Affari Internazionali ( $14^{\text {th }}$ October 2020$)<$ https://www.hrw.org/news/2020/10/14/war-and-covid19-yemen >
} 
portion of the country's economy to close down, resulting in unemployment spiking to its highest rate, hitting $14.7 \%$ earlier this year. ${ }^{16}$ Even though the US economy was closed down for quite some time, its overall impact was not as detrimental as that seen in low-income countries such as Yemen because of technological advantages enjoyed by the US and an advanced healthcare system.

\subsection{The long term effects of the global economic crisis}

At the time of this research, it is unclear which path the pandemic will progress into. The development of a vaccination is the deciding factor to determine the direction of the pandemic and its impact on the world. ${ }^{17}$ This research acknowledges two pathways which the pandemic may deviate towards. First would be the plausible scenario of a COVID-19 vaccine which would reverse the current prospects of a poor growth. Secondly, a possible outcome would be seen in the continuation of the pandemic and its aggravation on economies.

Taken individually, the application of the above scenarios on a macro-economic level to low-income economies can produce contradicting results. If a vaccination is to be produced and provided to the general public, the GDP per capita in developing countries could possibly increase by $3 \%$ above their current baseline. This could give an indication to policy makers to draft new policies that would substantially boost the economy. They may take into consideration the policies implemented during the pandemic, embedding the process of adaptation to national policies. However, if the pandemic was to continue as it is, a reduction of the GDP by $2 \%$ can be predicted. ${ }^{18}$ The pandemic might aggravate the existing weaknesses of developing countries such as high level debt, increase in business failures and bankruptcies, lack of fiscal space and weak education systems, leading up to a long-term stagnation of production growth. ${ }^{19}$

High-income economies, predominantly in Europe and North America, have strong real time surveillance and health systems to manage the spread of infectious diseases. Therefore, in a scenario where a vaccination is produced the GDP per capita in such countries will continue to increase at the same rate as it did before the pandemic but with mild

\footnotetext{
${ }^{16}$ Lauren Bauer, Kristen E. Broady, Wendy Edelberg, and Jimmy O’Donnell, Ten Facts about COVID-19 and the U.S. Economy $\left(17^{\text {th }}\right.$ September 2020) < https://www.brookings.edu/research/ten-facts-about-covid-19-and-the-u-seconomy/ >

${ }^{17}$ Anton Pak, Oyelola A. Adegboye, Adeshina I. Adekunle, Kazi M. Rahman, Emma S. McBryde and Damon P. Eisen, 'Economic Consequences of the COVID 19 outbreak: the need for Epidemic Preparedness' (Frontiers in Public Health, 29 May 2020) < https://doi.org/10.3389/fpubh.2020.00241 >

18 Julian Rodrick Slotman, Global Economic Monitoring Branch, Economic Analysis and Policy Division, UN DESA; The long-term impact of COVID19 on poverty (15th October 2020) 86-the-long-term-impact-of-covid-19-on-poverty/ >

19 Daniel Gurara, Stefania Fabrizio, and Johannes Wiegand, 'COVID 19: Without Help, Low Income Developing Countries Risk A Lost Decade' (IMF Blog, 27 August 2020), < https://blogs.imf.org/2020/08/27/covid-19-withouthelp-low-income-developing-countries-risk-a-lost-decade/ >
}

drawbacks. ${ }^{20}$ Policy makers might continue to draft new policies by scrutinizing the progress of other developed countries which would further enhance productivity. If the pandemic was to continue as it is, highly developed countries would not be as vulnerable as lower income countries because of their access to new technology and their ability to test new vaccinations. ${ }^{21}$ It is evident that there would be a slight decrease of the growth rate due to government lockdowns but citizens of these countries have the opportunity to adapt accordingly and with ease during these times due to their ability to access new technology.

\section{HAS COVID-19 CHANGED SOCIETY AS A WHOLE?}

Palpable changes have also reshaped modern society, most notably through the imposition of lockdowns and movement restrictions in attempts to slow down the spread of the virus. When discussing the social impact of the coronavirus, this research focuses on the educational, political, religious and psychological repercussions. The consequences of the COVID-19 pandemic stretch far beyond the spread of the disease. Despite the necessity of the aforementioned containment efforts, adapting to the current situation has proved to be rather difficult, as seen through the detrimental effect of the pandemic on the livelihoods of millions where the enforcement of quarantine measures have halted social gatherings and events, causing drastic changes in day to day lifestyles. This pandemic has also led society to create new norms such as social distancing, remote working, increased awareness of personal hygiene, temperature and security checks. In consideration of these emerging norms of social distancing, the governments have made it mandatory to maintain a distance of at least one meter between people and to wear a face mask when in public in order to reduce transmission of the virus. Thus, with the fear of contracting any diseases in the future people have and would grow accustomed to such safety measures. Similar to social distancing, remote working has also become a popular norm within the international society, as companies have halted onsight working, employers have started to provide the necessary equipment and software for their employees to facilitate remote working. The transition from on-sight working to remote working has been made easier through video conferencing software such as Zoom, Microsoft Teams, Skype and other such applications. Similarly, the progression of the education system from traditional methods to a more digitally oriented learning system can also be observed.

\footnotetext{
${ }^{20}$ Mike Patton, 'The Impact of COVID 19 on U.S. Economy and Financial Markets', (Forbes, 12 October 2020), < https://www.forbes.com/sites/mikepatton/2020/10/12/the-impact-of-covid-19on-us-economy-and-financial-markets/?sh $=59 \mathrm{a} 5 \mathrm{e} 46 \mathrm{a} 2 \mathrm{~d} 20>$

${ }^{21}$ Stephen Hodgins and Abdulmumin Saad, 'Will the Higher-Income Country Blueprint for COVID 19 work in Low- and Lower Middle- Income Countries?' (2020), Glob Health Sci Pract. 8(2) < https://www.ncbi.nlm.nih.gov/pmc/articles/PMC7326511/ >
} 


\subsection{The education crisis}

The global education system was under a crisis situation even before the occurrence of the coronavirus pandemic. Many states needed reformations in their education systems but were brought to a standstill due to internal strife such as civil wars and political unrest as well as international situations for instance financial crises and sanctions on major exporting countries. ${ }^{22}$ According to the UNESCO Institute for Statistics (UNIS), 387 million or 56 per cent of primary school age children world-wide were estimated to lack basic reading skills. ${ }^{23}$ The World Bank has also reported that 'around 53\% of young people in low- and middle-income countries live in "learning poverty". ${ }^{24}$ This led the UN to highlight education as a sustainable development goal in 2015. However, this goal has been overshadowed by the coronavirus pandemic which has created the largest disruption of education systems in history. By mid-April 2020, this pandemic had affected $94 \%$ of learners worldwide representing 1.5 billion children and youth falling within the categories of primary and higher education in 200 countries. The UNDP mentions that as a result of school closures during the second quarter of 2020 , $86 \%$ of children in primary education were unable to attend school in countries with low human development compared with just $20 \%$ in countries with high human development. ${ }^{25}$ The Sahel region in Africa has been experiencing nationwide school closures for several months before COVID-19 due to terrorist activities, armed conflicts and climatic hazards. ${ }^{26}$ Even though as of September 2021 some countries have adopted online class sessions, but however, it is a different story for students learning in rural areas where internet signal is very weak. In Sri Lanka, children in rural villages had to climb trees to in order to get signal to attend classes. ${ }^{27}$

Subsequently, the situation in Sub-Saharan Africa has been worsened due to the onset of the coronavirus which has interrupted the school year and has had a disproportionately negative impact on the most vulnerable pupils in the region. Since this region is in extreme poverty, it should also be noted that parents who depended on school meals now have to find solutions to provide care and compensate for the loss of

\footnotetext{
${ }^{22}$ COVID-19: Youth and Education: Impacts and Options (August 2020) < https://reliefweb.int/sites/reliefweb.int/files/resources/Note12_Covid19_Yout h.pdf >

${ }^{23}$ The UNESCO Institute for Statistics, More Than One-Half of Children and Adolescents Are Not Learning Worldwide, Fact Sheet No. 46 September 2017 < http://uis.unesco.org/sites/default/files/documents/fs46-more-thanhalf-children-not-learning-en-2017.pdf >

${ }^{24}$ Andreas Schleicher: The Impact of COVID 19 on Education in Sights from Education at a glance $(2020)<$ https://www.oecd.org/education/the-impactof-covid-19-on-education-insights-education-at-a-glance-2020.pdf >

${ }^{25}$ Shelby Carvalho and Susannah Hares, Six Ways COVID-19 Will Shape the Future of Education $\left(22^{\text {nd }}\right.$ July 2020) < https://www.cgdev.org/blog/six-wayscovid-19-will-shape-future-education >

26 Education during COVID-19 and beyond (August 2020) < https://www.un.org/development/desa/dspd/wp-

content/uploads/sites/22/2020/08/sg_policy_brief_covid-

19_and_education_august_2020.pdf >

${ }^{27}$ Sri Lankan children make a dangerous climb for online school | Sri Lanka News | Al Jazeera
}

school meals. According to the UNESCO Global Education Monitoring Report 2020, an estimated $40 \%$ of the poorest countries failed to support learners during the COVID-19 crisis due to the lack of adequate access to technology and other facilities. ${ }^{28}$ To combat the unprecedented loss of learning, many educational institutions and governments in a vast majority of countries, facing school closures have transitioned to remote teaching. ${ }^{29}$ This transition to remote learning has required experimentation and a reliance on preexisting communication software such as Skype and CISCO. In recent months, many education systems have adopted new and improved applications such as Zoom, Microsoft Teams and Google Classroom to ensure the continuity of education. ${ }^{30}$ The adaptation to a new educational system shows that this might continue for quite some time even after a possible end to the pandemic due to the efficiency and flexibility experienced by a majority of learners worldwide.

\subsection{The impact on religious activities}

Bans and limitations placed on social gatherings has also brought about a cease in the conducting of religious activities. Whilst this may have caused a disruption in religious practices, religious leaders have been quick to adapt to the circumstances by providing their devotees with the ability to engage in worship through the use of livestream facilities. ${ }^{31}$ Additionally, religious institutions have also been providing aid and assistance to those most affected by the global health crisis through the provision of necessities with some places of worship even offering free COVID-19 testing apparatus. ${ }^{32}$ Along with the cancellation of in-person worship, devotees have also had to celebrate religious festivals from home as seen through masses of Hindus celebrating Holi and offering pujas from home. ${ }^{33}$ Whilst it can be seen that religious leaders have been able to engage the support of their congregations in the efforts employed to curb the spread of the pandemic, some minorities have been found to have acted to the contrary. ${ }^{34}$ For

\footnotetext{
${ }^{28}$ The United Nations Educational, Scientific and Cultural Organization, UNESCO Global Education Monitoring Report $2020<$ https://en.unesco.org/gem-report/taxonomy/term/237 >

${ }^{29}$ Charles Hodges and others: The Difference Between Emergency Remote Teaching and Online Learning $\left(27^{\text {th }}\right.$ March 2020) < https://er.educause.edu/articles/2020/3/the-difference-between-emergencyremote-teaching-and-online-learning >

${ }^{30}$ The impact of COVID-19 on education systems and specialist provision (12th June 2020) < https://www.european-agency.org/news/impact-covid-19education-systems-and-specialist-provision >

${ }^{31}$ Katherine Marshall, What Religion Can Offer in the Response to COVID19 (May 2020) < https://www.worldpoliticsreview.com/insights/28789/religion-and-covid-19faith-during-a-pandemic >

${ }^{32}$ Religious inequalities and the impact of Covid-19 (September 2020) < https://www.ids.ac.uk/news/religious-inequalities-and-the-impact-of-covid$19 />$

${ }^{33}$ Coronavirus scare: PM Modi says no to Holi 2020. Why you should too (March 2020) < https://www.indiatoday.in/lifestyle/what-shot/story/coronavirus-scare-pm-modi-says-no-to-holi-2020-why-you-shouldtoo-1652333-2020-03-04 >

${ }^{34}$ Dr. Rajkumar Singh, Impact of Covid-19 on Religion and Beyond (June 2020) < https://thegeopolitics.com/impact-of-covid-19-on-religion-andbeyond/ >
} 
example, in South Korea it was found that gatherings at the Shincheonji Church of Jesus in the city of Daegu accounted for 5080 confirmed cases of COVID-19, more than half of the country's total number of cases as of late March. ${ }^{35}$ Another aspect of religious affairs affected by the pandemic is pastoral care. The importance of social distancing has resulted in a difficulty for religious leaders to adapt their methods in providing the sick with spiritual support and guidance, especially those under quarantine. ${ }^{36}$ Likewise, certain death and burial rites have also been affected due to the lack of substitute means of conducting such rites which are especially painful and needed in a pandemic that has claimed millions of lives. Restrictions placed on large gatherings have meant that funerals, a time for common fellowship, have had to be conducted with few, if any, people physically present.

It is also evident that public health measures for safe burial practices have clashed with traditional burial methods as seen in Sri Lanka, where authorities made it mandatory for deaths linked to coronavirus to undergo cremation. This occurred even though Islam forbids cremation and has led to religious tension within the country. ${ }^{37}$ Despite such occurrences, some religions have found alternative methods of performing such rites whilst adhering to safety measures. Another religious practice affected by the global pandemic has been religious charity which a vast majority of people rely on. The cessation of in-person worship and the closing of places of worship has affected members of religious communities who rely on social services provided by places of worship such as child care and hunger relief. Many religious leaders have teamed up with other charitable organizations and continue to provide aid to those in need, all while complying with safety measures as seen through their efforts to address the issue of food insecurity and also efforts made to assist the elderly and disabled. A collaboration between religious organizations and governments can be seen as a response to the pandemic in providing health and care overall. ${ }^{38}$ Religious leaders, together with local community leaders, are instrumental in conveying public health messages by simply urging people to stay home and wash hands. They can also incorporate religious stories from their respective religions to transmit basic public health suggestions in ways that are more easily acceptable. Amidst this crisis, a goal of a religious leader is to project messages of

\footnotetext{
${ }^{35}$ Youjin. S, Bonnie. B and Min. J, How a South Korean church helped fuel the spread of the coronavirus (March 2020) < https://www.washingtonpost.com/graphics/2020/world/coronavirus-southkorea-church/ >

${ }^{36}$ Simon Dein, COVID-19, mental health and religion: an agenda for future research (June 2020)

https://www.tandfonline.com/doi/full/10.1080/13674676.2020.1768725 >

37 Sri Lanka: Muslim COVID-19 victims cremated against families' wishes (April 2020) < https://www.amnesty.org.uk/press-releases/sri-lanka-muslimcovid-19-victims-cremated-against-families-wishes >

${ }^{38}$ Sheree Rose Nelson, Walden University 2020, Religious Tolerance and Government Collaboration with Faith-based Organizations based Organizations

https://scholarworks.waldenu.edu/cgi/viewcontent.cgi?article=10038\&context
} $=$ dissertations > public health and also invoke compassion and kindness amongst the community.

\subsubsection{Psychological aspect of the pandemic}

The psychological distress brought on by the pandemic has been very common worldwide. The restriction of social activities, as well as the prohibition of individual movements due to quarantine have caused some individuals to be trapped not only physically but also mentally. Many psychological problems in terms of mental health including stress, anxiety, depression, frustration and insomnia have emerged progressively as a result of the COVID-19 outbreak. These psychological issues are provoked through mass quarantine impositions and media. ${ }^{39}$ The media has been the primary reason for almost all the psychological reactions such as panic, feelings of hopelessness and desperation, abnormally elevated anxiety and suicidal behavior. As the general population becomes exposed to anxiety provoking topics relating to COVID 19 this causes lifestyle changes potentially leading to the onset of psychiatric conditions. The psychological impact of COVID 19 is more severe for frontline healthcare workers, as more critically ill patients started flooding into local hospitals, forcing hospital administrations to implement their emergency protocols. Due to these emergency procedures, most of the front-line healthcare workers became vulnerable to the emotional impact of COVID-19 and the consequences of the pandemic worldwide. $^{40}$ Thus, it can be seen that the dysfunctional psychological consequences of the pandemic can either be short term or long term, such as vigilant handwashing and avoidance of crowd months after quarantine has been lifted. ${ }^{41}$

\subsubsection{Government response to the pandemic}

The novel pandemic has had a critical impact on politics both at the national and international levels. This pandemic is changing how political leaders are making decisions on certain levels. A major expansion of government power is needed to combat the coronavirus and to protect the general public. Governments have exercised special executive power when imposing lockdowns and travel restrictions. Certain powers such as imposing curfews, strict military involvement, and police controlled areas are mandatory to keep the general public aware of the consequences of the pandemic. Impositions of such powers have undermined human rights and the democratic processes domestically. However, most

\footnotetext{
39 Dr Elke Van Hoof, Lockdown is the world's biggest psychological experiment - and we will pay the price (April 2020) < https://www.weforum.org/agenda/2020/04/this-is-the-psychological-side-ofthe-covid-19-pandemic-that-were-ignoring/ >

${ }^{40}$ Sonja Cabarkapa, The psychological impact of COVID-19 and other viral epidemics on frontline healthcare workers and ways to address it (October 2020) < https://www.ncbi.nlm.nih.gov/pmc/articles/PMC7494453/ >

${ }^{41}$ Cameron Fox, COVID-19 will have longterm effects on mental health. This expert explains how to limit the damage (October 2020) < https://www.weforum.org/agenda/2020/10/covid-19-will-have-longtermeffects-on-mental-health-this-expert-explains-how-to-limit-the-damage/ >
} 
governments responded to the crisis in many ways. ${ }^{42}$ Firstly, by making decisions in relation to the emergence of the crisis and any special powers that needed to be legislated. Secondly, by showing leadership and continuing to perform their legislative tasks, maintaining the state's constitutional balance and government accountability to the people in times of this crisis. Thirdly, by setting examples and establishing such as social distancing, prohibition of group meetings and curfews in respect to public health. Finally, by protecting the parliament's own safety. Some states such the United States of America and Denmark have emphasized that the state functions will be carried out by the governments despite the impact of the Coronavirus pandemic. ${ }^{43}$ The U.S. House of Representatives Speaker Nancy Pelosi had stated that a sea captain cannot abandon his ship until the last soul is saved, indicating that the U.S. Government would not cease its constitutional role ${ }^{44}$. Similarly, the Speaker of the Danish Parliament, Henrik Dam Kristensen made a parallel statement mentioning that it is crucial for the Danish society that they maintain the essential functions of the Danish Parliament to discuss and adopt emergency proposals and legislations which would steer the Danish society away from the current crisis. ${ }^{45}$ Italy, did not stop the legislative functions as the speaker of the Italian Chamber of Deputies Robert Fico stated that "the parliament must be at the forefront, it cannot go back, as doctors and other categories do not go back". ${ }^{46}$

Even though the pandemic demonstrated the value of decisive actions, this decisiveness does not reflect the effectiveness of the government. Authoritarian governments can be taken as a prime example that information provided to the public and to international institutions might be selective and geared towards covering up errors.

However, some parliaments adopted certain provisions that would monitor and question the moves of the government. In Brazil, a mixed committee of six legislators from each chamber of the parliament is monitoring the work of the government, including through virtual meetings. ${ }^{47}$ In Spain, committee oversight is carried out through a single nominated

\footnotetext{
42 Thomas Pepinsky, The Political and Economic Impact of Covid-19 in Southeast Asia (July 2020) < https://www.nbr.org/publication/the-politicaland-economic-impact-of-covid-19-in-southeast-asia/ >

${ }^{43}$ George Tsereteli, Parliaments must continue to function and serve the people during the coronavirus pandemic (31st March 2020) < https://www.euronews.com/2020/03/31/parliaments-must-continue-tofunction-serve-the-people-during-coronavirus-pandemic-view >

${ }^{44}$ Richard Cowan, Susan Cornwell, David Morgan: Pelosi resists closing Congress amid coronavirus crisis (11th March 2020) < https://www.reuters.com/article/us-health-coronavirus-congressidUSKBN20X317 >

${ }^{45}$ Christiansborg tightens requirements for the number of listeners (November 2020 ) < https://nord.news/2020/11/03/christiansborg-tightens-requirementsfor-the-number-of-listeners/ >

${ }^{46}$ Italy looks for EU consensus on rebuilding of Europe's economies after Covid-19 (April 2020)

$<$ https://www.rfi.fr/en/europe/20200422-italy-looks-for-eu-consensus-onrebuilding-of-europe-s-economies-after-covid-19>

47 Brazil, < https://www.ipu.org/country-compilation-parliamentary-
} responses-pandemic\#T > representative of each parliamentary group. ${ }^{48}$ In the Czech Republic, where the parliament was not sitting in March 2020, the government regularly informed the Parliamentary Bureau and political group leaders of emergent developments. ${ }^{49}$ In Trinidad and Tobago, as the potentially disastrous impact of the pandemic became clear in February 2020, the joint Public Accounts and Appropriations Committee of both Houses organized a special meeting in which all of the ministries involved in the coronavirus response were asked to explain their ministries' plans to deal with an outbreak in the country. ${ }^{50}$ These enabled parliamentarians to question them on plans, and also provided citizens with the opportunity to view and assess the performance of the government. To reduce the risk of infections, some governments opted for virtual hearings and made changes to the internal regulations to permit virtual sessions in time of this crisis. In Romania earlier this year, individual hearings for a number of cabinet members were carried out via video conferencing, while in the parliamentary chamber the country's MPs and senators, many wearing surgical masks, voted over several hours in small groups. ${ }^{51}$ The European Parliament met remotely to consider and approve the European Union's emergency measures to fight the pandemic, which includes immediate financial help to countries in need.

\section{A NEW FORM OF JUSTICE?}

The judiciary consists of courts, judges, magistrates, adjudicators and other personnel ${ }^{52}$. The judicial system is a key to protect the way of life as well as to uphold modern democracy. The judicial authority is also regarded as an active subject concurring with the policy-maker in the determination of public policy. The judiciary in general should not be subjected to any influence from the other branches of the government and private institutions. The concept of separation of powers is essential in carrying out the idea of judicial independence. An independent judiciary is beneficial for the citizens as it safeguards the rights and privileges that are vested to an individual by the constitution of the state. As an essential concept of modern democracy, judicial independence acts as the foundation for the rule of law. ${ }^{53}$ Some countries promote the independence of the judiciary by a special selection of judges and by setting up a consolidated fund

\footnotetext{
48 Spain, < https://www.ipu.org/country-compilation-parliamentaryresponses-pandemic\#T >

${ }^{49}$ Czech Republic, < https://www.ipu.org/country-compilation-parliamentaryresponses-pandemic\#T >

${ }_{50}$ Public Accounts and Appropriations Committee 2020 < http://www.ttparliament.org/committee_business.php?mid=17\&id=230\&pid= $28>$

51 IBA Litigation Committee, International Bar Association: Impact of COVID-19 on Court

Operations \& Litigation Practice (June 2020)

52 Queensland Parliament < https://www.parliament.qld.gov.au/documents/explore/education/factsheets/F actsheet_5.1_RoleOfTheJudiciary.pdf >

53 Courts \& Tribunals Judiciary < https://www.judiciary.uk/about-thejudiciary/the-judiciary-the-government-and-the-constitution/jud-accind/independence/ >
} 
which would give a stable and adequate income within the tenure.

\subsection{The system prior to and during the pandemic}

In the early 2000's, the concept of judicial independence was embedded into the Australian constitution through the case of North Australian Aboriginal Legal Aid Service Inc v Bradley, which stated that the judiciary should be independent and impartial. ${ }^{54}$ Similarly, in the United Kingdom a Supreme Court was established through the Constitutional Reforms Act 2005, which came into effect in 2009. Before the introduction of the Supreme Court, the House of Lords acted as the highest judicial authority in the UK. The House of Lords being the highest court was a scar in the face of democracy in the UK as it was a part of the upper house and was heavily influenced by the supremacy of the Westminster parliament. The establishment of the Supreme Court in 2009 replaced the House of Lords as the highest judicial authority in the UK and was separated from the parliament to act as an independent body. This was considered to be a major step for the UK in protecting the judicial independence of the state. ${ }^{55}$ In the United States of America, the due process of law is preserved in the Bill of Rights which was ratified in 1791. Furthermore, through the case of Marbury v. Madison the United States Supreme Court recognized the power of judicial review which strengthened the judicial independence in the U.S ${ }^{56}$ The U.S. Constitution protects judicial independence in two ways. Firstly, Article III states that federal judges may hold their positions "during good behavior." In effect, they have lifetime appointments as long as they satisfy the ethical and legal standards of their judicial office. Secondly, Article III states that the legislative and executive branches may not combine to punish judges by decreasing payments for their services. ${ }^{57}$

The constitutions of some democratic countries provide appointments to the judges for a specific period of time, but invariably they protect their independence of action during their terms of office. Unfortunately, however, judicial independence is poorly protected in countries with internal political struggles and warfare. The governments in such countries fail to focus on protecting judicial independence as their main focus is to protect national security and end such internal issues.

This research emphasizes on countries such as Sri Lanka, Pakistan and Zimbabwe which have failed to protect judicial independence due to the corrupt nature in governance. The

\footnotetext{
54 'Judicial Independence and Judicial Accountability at the Coalface of the Australian Judiciary'

https://localcourt.nt.gov.au/sites/default/files/judicial_independence_and_judi cial_accountability_at_the_coalface_of_the_australian_judiciary_.pdf $>$

${ }^{55}$ Courts and Tribunals Judiciary, ' The Supreme Court' < judiciary.uk/aboutthe-judiciary/the-justice-system/the-supreme-court/ >

${ }_{56}^{56}$ <ttps://www.loc.gov/rr/program/bib/ourdocs/marbury.html >

57 Annenberg Classroom 'Judicial Independence' < https://www.annenbergclassroom.org/glossary_term/judicial-

independence/\#: :text=The\%20U.S.\%20Constitution\%2C\%20for\%20exampl e,standards $\% 20$ of $\% 20$ their\%20judicial\%20office. >
}

government of Sri Lanka, in 2013, with its large parliamentary majority impeached its Chief Justice Shirani Bandaranayake by inconveniently declaring an unconstitutional path of its legislative agenda. The government accused Bandaranayake for mis-applying the law and for misconduct although her decision was constitutionally correct and did not amount to misconduct. However, she was found guilty by a parliamentary select committee composed of 7 government ministers. ${ }^{58}$ This was a major drawback for the Sri Lankan judiciary as it was internationally criticized for being politically biased. The judicial system of Pakistan has been accused of corruption as its judges are being bribed by highlevel politicians and government officials. Corruption amongst low-level judges continues unabated and political bias influences the outcome of politically sensitive cases ${ }^{59}$. Similarly, in Zimbabwe President Mugabe personalized the judicial system and gifted land and goods to ensure the loyalty of the judges. Those who were not loyal to the government were removed through a combination of physical and psychological threats of violence. ${ }^{60}$ The appointment of judges was solely based on the influence of the Executive.

This research notes that the current pandemic has impacted the independence of the judiciary in such a way that it, in some instances, has cancelled the concept of separation of powers. As states enact emergency regulations to counter the spread of COVID-19, judicial oversight of the implementation of emergency measures is critical to avoid the excessive use of emergency powers. However, certain law-making institutions have been controversial and negligent in responding to the pandemic. ${ }^{61}$ In India, for instance, Prime Minister Narendra Modi gave his government significant powers when he declared a state of emergency in late March of 2020, paving the way for him to impose one of the strictest lockdowns anywhere in the world. ${ }^{62}$ More recently, in September 2021, the emergency laws that were declared by the president of Sri Lanka has overridden separation of power in a country that has a history of declaring emergency laws. ${ }^{63}$ These executive mandates have entrenched the functions of the judiciary in holding certain government institutions

\footnotetext{
58 Impeachment of the Sri Lankan Chief Justice (January 2013) < https://www.crisisgroup.org/asia/south-asia/sri-lanka/impeachment-srilankan-chief-justice >

${ }^{59}$ Shantanu Mukharji, Judiciary in Pakistan: Flawed judgments and fallacies plague country's fractured justice system (June 2017) < https://www.firstpost.com/world/judiciary-in-pakistan-flawed-judgments-andfallacies-plague-countrys-fractured-justice-system-3645669.html >

60 Dewa Mavhinga, Zimbabwe Constitutional Court May Lose its (July 2017)

https://www.hrw.org/news/2017/07/27/zimbabwe-constitutional-court-maylose-its-independence >

${ }^{61}$ Stephen Thomson, COVID-19 emergency measures and the impending authoritarian pandemic, Journal of Law and the Biosciences (September 2020) article/doi/10.1093/jlb/lsaa064/5912724 > https://academic.oup.com/jlb/advance-

${ }^{62}$ Subodh Varma, COVID-19: How the Pandemic Was Used to Grab All Power (May 2020) < https://www.newsclick.in/COVID-19-Pandemic-IndiaNarendra-Modi-Centralisation-of-Power $>$

${ }^{63}$ Sri Lanka parliament approves state of emergency | Food News | Al Jazeera
} 
accountable for misconduct. COVID-19 has exacerbated the entrenched nature of the judiciary which has had an unprecedented effect on the functioning of justice systems globally. This has resulted in the closure of courts and has reduced their operations which has affected their ability to provide timely and fair hearings. Court closures have contributed to an increase in the accumulation of cases and also prolonged judicial and administrative proceedings.

\section{SOCIETY ADOPTING TO A NEW JUSTICE SYSTEM}

The ongoing pandemic has barred the ability of courts to conduct hearings and trials in a physical courtroom, as a result of which courts and tribunals are now being encouraged to take matters remotely and virtually in order to ensure that access to justice remains available to the public. ${ }^{64}$ It should be noted that remote hearing is a concept that is not unfamiliar in resolving disputes. ${ }^{65}$ Some jurisdictions tend to prioritize remote hearing according to the courts' discretion and view of the case. The priority of a case for remote hearing is determined by three categories. Firstly, cases that surround essential areas of life such as personal safety, child custody and access to healthcare. The England and Wales Family Court held in the case of $\operatorname{Re} P$ (a child: remote hearing) [2020], to bat on and hear the case remotely and the court attempted to hear the matter over Skype. ${ }^{66}$ Similarly, the Supreme Court of California conducted a number of cases involving domestic violence and family law through remote hearings. ${ }^{67}$ Secondly, the courts would adopt remote hearings for issues such as guardianships, uncontested divorce and probate proceedings. Here, the parties should give adequate notice to opt to a remote hearing and the requirements documented between the parties for a remote hearing or a different method of resolving disputes should be satisfied. Thirdly, the courts would tend to opt for remote hearings for mandatory settlements and to reduce the backlog of cases that are scheduled to take place when courts are fully reopened. Some of the mandatory settlements include serious criminal evictions and disputes involving high-profile transactions.

\subsection{The scope of a remote hearing}

The field of international arbitration and courts have not been immune to the challenges arising out of travel restrictions and physical distancing imposed by different states. Since parties to the hearings, counsels and witnesses are located in different states, conducting a physical hearing is not feasible. There has

\footnotetext{
64 International arbitration and COVID-19: reconsidering the hearing $<$ https://corrs.com.au/insights/international-arbitration-and-covid-19reconsidering-the-hearing $>$

65 ibid

${ }^{66}$ Re P (A Child: Remote Hearing) [2020] EWFC $32<$ https://www.familylaw.co.uk/news_and_comment/re-p-(a-child-remotehearing)-2020-ewfc-32 >

${ }^{67}$ Cheryl Miller, How COVID-19 Is Impacting California Courts: Roundup of Services (September 2020)

https://www.law.com/therecorder/2020/07/13/how-covid-19-is-impactingcalifornia-courts-roundup-of-services/?slreturn=20201028105944 >
}

been an increase in demand by courts and tribunals in opting for hearings to be conducted remotely. Certain consideration of several specific issues that do not apply to physical hearings should be coordinated and harmonized in advance to a remote hearing. ${ }^{68}$ A remote hearing is a method of dispute resolution conducted by a court or an arbitral tribunal through telephone or video conference. It is the courts' duty to conduct the proceedings in a manner that is efficient with consideration to the scale of disturbance to the proceedings. ${ }^{69}$ There are a range of factors that render a physical hearing unsafe such as participants being in close proximity of each other in an enclosed space where the transmission of the virus is more likely to occur. In response to this, special measures have been implemented including requirements such as maintaining a physical distance of 1.5 meters, ensuring a proper circulation of clean air, ensuring that tables, chairs and other furniture used by the participants are disinfected and all participants should wear masks for extended periods of time. Despite these safety precautions, issues may still arise where it is not possible to always maintain the required physical distance in conference rooms. Similarly, the reliance on air conditioning may be insufficient in sanitizing the air and equipment in conference rooms whilst frequent disinfections may cause disturbances to the flow of proceedings. Moreover, wearing masks for prolonged periods of time causes discomfort and may interfere with the examination of witnesses. Since an in-person hearing is an inadequate method to resolve disputes, hearings by video conferences or remote hearings may offer more advantages in terms of flexibility and efficiency as well requiring preparation that goes beyond the familiar planning process. ${ }^{70}$

\subsection{A new procedure}

The procedural order of a remote hearing will differ from case to case. It would also differ in accordance to technological developments and requirements. ${ }^{71}$ The first phase of a remote hearing would be the pre-hearing video conferences. A prehearing conference should be scheduled before the actual hearing in order to resolve any outstanding procedural and administrative preparations. The pre-hearing conference should be conducted through video as a trial run in order to verify the proper functioning of the video conference system. Each party to the hearing should join the pre-hearing conference with the same device and internet connection they wish to use for the hearing. The pre-hearing conference should also test the communication software needed for the hearing. After the successful test run, the courts/tribunals should consult with the parties the preparation and agenda for the hearing. During the remote hearing, all participants are

\footnotetext{
${ }^{68}$ Chahat Chawla, International Arbitration During COVID-19: A Case Counsel's Perspective (June 2020) < http://arbitrationblog.kluwerarbitration.com/2020/06/04/internationalarbitration-during-covid-19-a-case-counsels-perspective/ >

${ }^{69}$ ibid

${ }^{70}$ California Commission on Access to Justice: Remote Hearings and Access to Justice (2020)

${ }^{71}$ ibid
} 
required to use a computer with an in-built or external camera as well as a functioning audio system to access the software. The courts tend to discourage the participants from using smartphones as the device on which they participate in the hearing due to inconveniences in quality of both audio and video. The courts/tribunal should authorize an external service provider or court personnel as the host of the meeting. As the host, the court personnel/external service provider is given the authority by the courts/tribunal to manage the entire proceedings. All actions of the host are to be carried out under the supervision of the court/tribunal. The host has the right to assign participants to specific meeting rooms which include the main meeting room where the hearing is to be conducted, and a total of three breakout rooms; two for the two parties involved in the dispute and one for the tribunal. These "rooms" are personalized and encrypted so that no participants can hear or see the discussions taking place in the other virtual rooms. ${ }^{72}$ Prior to the commencement of the virtual hearing, participants are required to join the meeting upon which they will be kept in a waiting room until all participants are present. The host will then admit each participant into the main meeting or their respective breakout rooms. Access to the court proceedings in a remote hearing will be restricted to the members of the court, the parties involved in the dispute and the list of participants provided by the parties. It is the parties' responsibility to be sufficiently equipped with broadband connectivity and necessary devices such as microphones, cameras and headsets with additional backup devices in order to conduct the remote hearings efficiently and without delay.

All participants to the hearing should adjust their cameras in a manner that their head and torso be visible with adequate lighting. Furthermore, the parties should not interfere with the speaker, in order to raise an objection, the counsel may simply raise their hand to contact the judge/arbitrator. These are etiquettes that should be adhered to by the parties at all times when video conferencing. ${ }^{73}$

Parties have the liberty to present evidence directly using PowerPoint presentation or other visual aids. The parties should disclose these PowerPoint presentations to the opposing party and the court/tribunal by email before the hearing. During the hearing, the parties shall designate a document manager from each side who in turn will be responsible for managing the evidence. The parties can also agree to use an encrypted document server where they can ensure the security of the documents from unlawful third party intervention. Witnesses can now give evidence from an independent remote location with the presence of an independent supervising officer who should be appointed by the court. Their main task is to minimize the risk of witness

\footnotetext{
72 Enabling breakout rooms < https://support.zoom.us/hc/enus/articles/206476093-Enabling-breakout-rooms >

73 The Transparency Project: Guide to Remote Court Hearing (2020) < http://www.transparencyproject.org.uk/press/wp-content/uploads/REMOTECOURT-HEARINGS-GUIDE-FINAL.pdf >
}

coaching which could affect the integrity of the procedure and jeopardize the dispute. The courts may take a step further to mitigate the risk of undue interference by including the use of a 360-degree owl camera and requiring witnesses to stay on screen during breaks. Tribunals may temporarily or permanently suspend the hearing if it deems the functioning of the video conference inadequate or likely to cause prejudice to the due process rights to either of the parties or the integrity of the proceedings.

After consulting with the parties to the dispute, the court/tribunals can order the host of the remote hearing to record the entire proceeding. The audio or video recordings shall be made available to the parties upon their request and only the main room recordings will be taken. Due to cyber security and data protection, the recording should be made by the host of the remote hearing on the host's computer. It is also recommended that audio recordings to a remote hearing should be saved on a separate device as well. This is to ensure that the recordings are protected and backed up for later use. ${ }^{74}$ The courts/tribunals can scrutinize the missed non-verbal cues and body language during cross examination of the witness through the recorded videos. The courts have the functionality to pause, rewind, fast-forward as well as the zoom option to further scrutinize facial expressions and suspicious movements. Finally, in order to combat the risk of an unauthorized third party interference, the courts and the parties should draw up cyber security protocol. ${ }^{75}$ The Cybersecurity Protocol provides a recommended framework to guide courts/tribunals, parties, and administering institutions in their consideration of what information security measures are reasonable to apply to a particular proceeding. ${ }^{76}$

\subsection{Drawbacks of this new system}

This research asserts that even though remote hearings are appropriate in such times, it is still subjected to many disadvantages. There are many softwares available for video conferencing, which includes Skype for Business, MS Teams, Zoom and CISCO. None of these platforms are difficult to use because they offer good user guidelines/videos on their websites. ${ }^{77}$ The legal professionals have a role in making sure that their clients have the knowledge to use these platforms. However, these platforms have some drawbacks. For example, in Zoom, a session is limited to only forty minutes unless the unlimited service has been purchased. Zoom sessions also do not have end-to-end encryption which is a major concern as an unauthorized third party has the ability to easily hack the session, this policy was recently updated by adding end-to-end encryption. ${ }^{78}$ Many Cloud video platforms

\footnotetext{
${ }^{74}$ Presidential Task Force on Cyber Security, International Bar Association, Cyber Security Guidelines (2018)

https://www.ibanet.org/LPRU/cybersecurity-guidelines.aspx >

${ }^{75}$ ibid

${ }^{76}$ ibid

77 Skype for Business help \& learning < https://support.microsoft.com/enus/skype-for-business >

${ }^{78}$ Brian Barrett, Zoom Finally Has End-to-End Encryption (November 2020)

< https://www.wired.com/story/how-to-enable-zoom-encryption/ >
} 
have been subjected to numerous delays. These delays have caused hindrances to proceedings, sometimes compelling the trial judge to cease remote hearings. Even though breakout rooms are extremely useful, not many platforms have this option. The platforms that do have this require a subscription package which involves a big price tag. These hearings involve many new technologies such as new cameras and microphones as well as a well reputed and trusted service provider. These requirements for a remote hearing can be very costly for the parties involved in the dispute because acquiring the latest cameras and other equipment is an unnecessary cost. Acquiring a trusted service provider as a host for the hearing would be a disadvantage as the obligations of the host would be limited to their subscription package, the cost of which is added to the costs borne by the parties involved. Even though remote hearings would cut down the costs for travelling and accommodations, the costs for the required technologies would supersede other cuts in costs. ${ }^{79}$ Remote hearings in general require more time than an in-person hearing because the technology needed for the hearing takes a longer time to be set up. These hearings also tend to be more tiring and would require frequent intervals between procedural sessions.

Some hearings are not suitable to be conducted remotely, especially cases that involve interpreters. This is because having interpreters/court personnel present with the witness during witness examination gives rise to a question of party confidentiality as the interpreter will have access to certain sensitive information regarding the case. This also includes cases involving witnesses with certain disabilities which prevent them from taking part in a remote hearing. Since party equality is an essential concept in courts and tribunals, both parties should have access to certain technology. The remote hearings cannot proceed if only one party has such access. ${ }^{80}$ Therefore, the lack of telephones, internet connections or computers that were discussed as essentials in the pre-trial, will cancel the remote hearing. In remote hearings, since the court/tribunals cannot physically see the witness or expert, there is a possibility that they would be trained to present their statements in such a way that it would be advantageous to a certain party. This is a major disadvantage to a remote hearing as it would discourage certain parties to continue the remote hearing.

\section{A NEW SYSTEM IN PRACTIC}

This research focuses on Argentina, England and Wales, Italy and Malaysia which have taken remote hearings into consideration and have embedded provisions considering remote hearings into national statutes. Attention is given to the impact of COVID-19 on the operation of courts,

\footnotetext{
79 Adam Grant, Remote hearings in costs proceedings (May 2020) < http://disputeresolutionblog.practicallaw.com/remote-hearings-in-costsproceedings-the-new-normal/ >

${ }^{80}$ John Horan, Remote hearings: equality in the new 'normal'? < https://www.lag.org.uk/article/208449/remote-hearings--equality-in-the-new--
} normal-- > government passed legislation recognizing a specific method of hearing and the adaptation and practice of the courts.

\section{a. Argentina}

The Argentine judicial system is divided into federal courts which is organized by the Federal government and includes the Court of First Instance, the Appellate Courts and the Argentine Supreme Court of Justice. The local courts are organized by the provincial governments and include the court of appeal and local Supreme Courts. The Federal Courts overlook cases which involve the National Constitution, the Federal law or international treaties while local courts enforce local laws and traditional laws. ${ }^{81}$

The impact of the COVID-19 pandemic forced the Argentine court system to adopt regulations for temporarily suspending normal operations until further notice. In-person hearings were suspended due to the government mandate lockdowns and social isolation established by the Argentine executive. However, in order to solve urgent matters involving criminal cases, family issues, matters involving protection of minors, gender related matters as well as health issues, the courts have appropriated a series of measures adopting certain provisions of justice (Agreement No. 3/2020). ${ }^{82}$ The Argentine court system has also adopted a proceeding known as the Amparo proceedings which is a special type of summary proceedings that guarantees constitutional rights ${ }^{83}$. National and Federal courts were entrusted with the ability to appoint their employees to deal with as many matters as possible.

The Supreme Court of Justice of Argentina has established through sections 286 and 288 of the Argentine Civil and Commercial Code, a remote filing system to electronically file claims, appeals and complaints before a particular court. ${ }^{84}$ This system has reduced the necessity for citizens to come to courts and file their claim. Due to the pandemic, the courts will not resume their activities soon but the implementation of new technological mechanisms will continue the functioning of the courts. According to Argentine procedural rules, the examination of a witness is valid when it is taken to court. If the examination is conducted virtually it creates a procedural issue, theoretically the witness examination should be suspended until courts resume their activities. However, the Argentine courts are encouraged to decide upon taking witness examinations through video conferences. This would protect parties' rights and guaranties. The federal and national courts of the city of Buenos Aires have reminded the judges

\footnotetext{
${ }^{81}$ Dr.Gisela Monge Roffarello and others, A Research Guide to the Argentine Legal System (2006)

https://www.nyulawglobal.org/globalex/Argentina.html >

${ }^{82}$ Impact of COVID-19 on Court Proceedings and Mediations in Argentina (October 2020) < https://www.marval.com/publicacion/impacto-en-procesosjudiciales-y-mediaciones-13554\&lang=en >

${ }^{83}$ Gloria Orrego Hoyos, The Amparo Context in Latin American Jurisdiction: An Approach to an Empowering Action (October 2007) < https://www.nyulawglobal.org/globalex/Amparo1.html >

${ }^{84}$ Argentina Commercial Code < https://ppp.worldbank.org/public-privatepartnership/sites/ppp.worldbank.org/files/documents/Ley15.349(1946)_SP_0. pdf >
} 
involved in hearings which require extensive witness examination, to take into account the use of available technological tools (Agreement 12/2020). The Argentine Ministry of Justice has applied similar steps to Mediation where mandatory mediation proceedings prior to the commencement of the judicial proceedings have to be conducted through video conferencing.

\section{b. England and Wales}

The first reported case of COVID-19 was confirmed on the 31 st of January. Following this there was a swift response by the UK government and the courts to the pandemic where the Lord Chief Justice published an announcement on the 19th of March stating that the judiciary will conduct its obligations and will not grind to a halt. Furthermore, he went on to state that the Ministry of Justice and the courts will be working together to develop and continue proceedings through telephone and video technology. ${ }^{85}$ The courts will take immediate action to hold remote hearings whenever possible, and ensure as many hearings in all jurisdictions to proceed and continue with all urgent matters. The UK commercial court system has introduced four kinds of hearings. First would be a fully remote hearing with the Judge at home. Secondly, a fully remote hearing with the Judge in their office/court. Thirdly would be a hybrid hearing with the Judge and some participants in courts with others joining remotely, and finally a normal physical hearing with all the participants attending in person. In a physical hearing, the number of people permitted in a single court at any given time will be limited to ensure social distancing. In order to assist the traditional courts to manage their cases, a working group has been established to start identifying suitable venues such as civic centers and other public places to be used as "Nightingale" courts. Nightingale Courts are temporary courts established by the judicial system to tackle the increase in backlog of legal cases brought forth by the pandemic. These courts are mainly focused for cases involving family matters, cases involving tribunals and non-custodial criminal cases. ${ }^{86}$

UK courts have established a method to file certain claims online in any event using a CE-file system. This system, however, was established prior to the COVID-19 pandemic and has been overused due to the increase in E-filings and reduced court staff to deal with the claims. ${ }^{87}$ The UK government introduced the Coronavirus Act 2020 which has included measures to assist the Courts in operations regarding remote hearings. The Act has included provisions to enable video and audio hearings to be broadcasted to the public as well as to direct the courts to record the proceedings. ${ }^{88}$

\footnotetext{
${ }^{85}$ Coronavirus (COVID-19) update from the Lord Chief Justice (March 2020) https://www.judiciary.uk/announcements/coronavirus-update-from-thelord-chief-justice/ >

${ }^{86}$ Coronavirus: Ten 'Nightingale Courts' in England and Wales to open (July 2020) < https://www.bbc.com/news/uk-53463856 >

87 E Filing < https://www.judiciary.uk/you-and-the-judiciary/going-tocourt/high-court/the-rolls-building/e-filing/ >

$88 \quad$ Coronavirus Act

https://www.legislation.gov.uk/ukpga/2020/7/contents >
}

Furthermore, the Civil Justice in England and Wales Protocol Regarding Remote Hearings was issued by the UK courts on the 26th of March 2020. This sets out a guide to conduct such hearings and also recommends certain software such as Skype for Business and Microsoft Teams to conduct the proceedings and to upload electronic court bundles. Finally, a new practice direction (PD 51Y) was introduced which enabled the courts to move from a public hearing to a private hearing which would allow it to proceed remotely. ${ }^{89}$

The approaches made by the UK courts have been supported by case law solidifying the provisions taken to combat the issues experienced in court proceedings due to the pandemic. The Deputy High Court Judge in the case of Re One Blackfriars Ltd v Nygate (2020), agreed with the respondent's submissions and refused to adjourn a five-week trial of a claim by joint liquidators against former administrators of a company. ${ }^{90}$ The court refused the application to adjourn the trial and the parties were ordered to prepare for trial to be conducted remotely. The case considered safety, technological challenges and equality of the parties. The claimant asserted that their expert witnesses were struggling to participate in a remote hearing. However, the judge rejected this and stated that if the difficulties do exist, certain alternative arrangements can be made in order to complete the expert examination and the expert reports. In this matter, the judge took the safety concerns into account and, considering the available technological tools and continued the proceedings without delay. The claimant next submitted the unavailability of technology to deliver a successful remote trial with each participant in different locations. The learned judge rejected this submission as he was not satisfied that the technological challenges were so great as to make it appropriate to adjourn the trial. The judge then ordered parties to co-operate in seeking potential remote trial platforms and document handling systems, and to inform the court of these 'realistic arrangements'. The learned judge further held that any proposed system by the parties would be subject to robust testing from as many locations from which the participants are likely to be giving evidence and to ensure that documents can be displayed quickly. Additionally, the issue of broadband connection and bandwidth was also essential and the learned judge suggested that it may be preferable for witnesses to travel to locations close to their homes, such as solicitors' offices with dedicated servers and IT staff on hand. The claimant finally emphasized the issue of party equality however, the learned judge held that this litigation was between well-resourced sophisticated parties which had excellent legal teams. As such, there was equality of arms in

\footnotetext{
${ }^{89}$ Practical Law Dispute Resolution, COVID-19: Judiciary publishes revised protocol on remote hearings in County Court, High Court, Business and Property Courts and Court of Appeal (Civil Division) (March 2020) < https://uk.practicallaw.thomsonreuters.com/w-0248069?transitionType $=$ Default\&contextData $=($ sc. Default $) \&$ firstPage $=$ true $>$ ${ }^{90}$ Re One Blackfriars Ltd, Hyde v. Nygate [2020] EWHC 845(Ch) < https://www.judiciary.uk/judgments/adrian-charles-hyde-and-kevin-anthonymurphy-v-anthony-david-nygate/ >
} 
that the challenges and upsides of proceeding with a remote trial will apply to both sides equally.

Similarly, in the case of Muncipio De Mariana \& Ors $v$ BHP Group Plc (2020) the dispute between parties related to the collapse of the Fundao Dam in Brazil in 2015..$^{91}$ The defendants were seeking a stay of proceedings before the Technology and Construction Court as court proceedings had already been launched in Brazil. However, the pandemic had given rise to two issues, the first of which was whether an extension of time would be allowed. The learned judge allowed this request for the gathering of evidence and acknowledged the difficulties that may arise when working remotely where expert witnesses, for instance, were based in Brazil and did not have access to staff and the library due to the lockdowns that were imposed. The second issue that arose was whether the jurisdictional dispute could be fairly resolved by way of a remote hearing where the judge considered that live evidence would not be involved and that the issue would be determined through skeletal submissions and oral arguments presented by the parties. Thus, it was held to be a matter capable of being fairly determined in a remote hearing.

Pertinently, with the reliance on previous authorities including Re One Blackfriars Ltd which sets out key principles for remote hearings and legislations enacted by the UK government such as the Coronavirus Act 2020 has encouraged courts and tribunals to hold proceedings remotely avoiding delays? It is worth mentioning that with the practice of remote hearings in times of the pandemic will decide the future of this virtual method in litigation and dispute resolution. Case law and statutes have been placed, giving prominence to remote hearings and its adoption for certain cases in the future.

\section{c. Italy}

On the 31st of January, the first cases of the virus were reported and subsequently, by the end of March, the virus spread to all regions in Italy. This European Nation reported the highest death toll in Europe during the first wave of the virus. The Italian government initiated a framework of general lockdowns and several measures to identify clusters and control the spread of the virus. On $31^{\text {st }}$ January 2020, the Italian Government formally declared the state of emergency pursuant to Legislative Decree 1/2018 of the Civil Protection Code. Article 24 of Italian Civil Protection Code rules that the government can declare a state of national emergency, which has to be limited in duration (12 months maximum) and determine its territorial scope, with reference to the nature and character of events $^{92}$. In consideration, the government issued a decree establishing a suspension of the court proceedings

\footnotetext{
91 Muncipio De Mariana \& Others v BHP Group PLC (formerly BHP $\begin{array}{lllll}\text { Billiton } & {[2020]} & \text { EWHC } & 928 & \text { (TCC) }\end{array}$ https://www.hilldickinson.com/insights/articles/muncipio-de-mariana-othersv-bhp-group-plc-formerly-bhp-billiton-2020-ewhc-928-tcc >

${ }^{92}$ Nicola Canestrini, Covid-19 Italian emergency legislation and infection of the rule of law (June 2020) < https://journals.sagepub.com/doi/full/10.1177/2032284420934669 >
}

from 9th March to the 11th of May, this period was known as the "Emergency Period".

According to Article 83, paragraph 1 of the Law-Decree No. 18 (Decreto Curia Italia), "the hearings of the civil and criminal proceedings pending in front of all judiciary offices are postponed ex officio". However, Paragraph 3 of the same article provides a number of cases in which the deferral of court hearings, as well as the suspension of deadlines, did not apply. ${ }^{93}$ The exception was made in regards to urgent matters specifically acknowledged by the court, even, in case, upon specific request of the parties. Exceptions include dealing with minors, regarding maintenance obligations, for cautionary measures dealing with the protection of fundamental human rights, for the adoption of measures on issues relating to tutorship, support administration, interdiction and incapacitation. The Article further includes matters regarding pregnancy interruption after the first 90 days and for the adoption of urgent protection orders against family abuses, for validation of expulsion, removal and detention of third countries and EU nationals. $^{94}$

Decreto Curia Italia provides a "Buffering Period" (12th May to 31 st July), during which "the heads of the judicial office adopt the organizational measures, including those concerning the handling of judicial affairs, necessary to allow compliance with the hygienic-sanitary indications provided by the Ministry of Health". ${ }^{95}$ The judicial system was encouraged to conduct hearings in two methods. Firstly, Article 83, paragraph $7(\mathrm{f})$ of the Decreto Curia Italia introduced the method of remote connections, where the presence of the persons other than the parties, the parties' counsels and the judge is not required. The judge should give the parties prior notice of the time and method of connection, and then record in the minutes of the hearing the method of ascertaining the identity of the subjects involved and, as to the parties in person and their consent. ${ }^{96}$ Secondly, Article 83, paragraph 7(h) introduced the method of written discussion, where the presence of persons other than the parties' counsels is not required and the hearing will take place only in writing, through the mere exchange between the parties' counsels, and electronic filing, of written notes only containing the respective submissions and conclusions, with the subsequent out-of-court adoption of measures/orders by the judge. ${ }^{97}$

Italian government expressly acknowledged that legal and accounting activities should be guaranteed to citizens in cases of necessity and urgency. Therefore, lawyers and accountants had to guarantee their service to the citizens while respecting the prevention and protection measures imposed by the

\begin{tabular}{l}
\hline \multicolumn{1}{c}{ Law-Decree } \\
$93 \quad$ No.
\end{tabular}


authorities. Smart work from home was to be preferred and meetings with clients and colleagues are mainly held through video conference platforms. On $20^{\text {th }}$ March 2020, the General Director of Information and Automated Systems of the Ministry of Justice identified programs such as "Skype for Business" and "Microsoft Teams" to be suitable for such conducts.

\section{d. Malaysia}

The Malaysian government imposed certain restrictions in movement to combat the spread of the virus. A nationwide Movement Control Order (MCO) was announced on the 16th of March 2020 and required all government and private business premises to be closed, except for those providing essential services. ${ }^{98}$ This restriction order continued for 47 days and when COVID-19 cases reduced, the government amended the MCO and added a conditional provision loosening the initial restriction order. According to the Prevention and Control of Infectious Disease Act 1988, judicial and legal services are excluded from the list of essential services. ${ }^{99}$ Therefore, the courts and offices of advocates and solicitors were not in operation until the MCO was lifted. However, the courts deployed various measures to safeguard the access to justice during this period. The judiciary stated that all hearings, which were scheduled to take place during the MCO period, should be postponed until a future date to be decided by the parties and the court. Furthermore, claims could be filed through e-filing, however, courts without the e-filing facility could accept the filing of documents only once the MCO had been lifted as well as civil cases by way of online e-review would continue, but matters scheduled for manual case management were postponed until a future date, to be decided by the parties and the relevant court.

Parties were able to apply for a remote hearing through exchange of emails or video conferences, for matters regarding the agreement of all parties, court discretion, cases filed with a certificate of urgency or as otherwise directed by the courts. The judiciary even took it a step further by allowing the Court of Appeal to live-stream the hearings. This enabled the public to observe the hearing, replicating the public gallery in an open court. To facilitate the online hearings process, the judiciary also issued guidelines on conduct of proceedings via Skype for Business or other appropriate video conferencing platforms. The judiciary has introduced an e-appellate system to the High Court, this refers to a paperless proceeding where the physical copies of

\footnotetext{
98 The Situation in Malaysia < https://www.flandersinvestmentandtrade.com/export/nieuws/corona-virus$\%$ E2\%80\%93-situation-malaysia >

99 Alliff Benjamin Suhaimi, The Applicability of the Prevention and Control of Infectious Diseases Act 1988 in relation to the spread of COVID-19 (March 2020) < https://www.thomasphilip.com.my/articles/the-applicabilityof-the-prevention-and-control-of-infectious-diseases-act-1988-in-relation-tothe-spread-of-covid-19/>
}

documents are no longer required. Nonetheless, the physical presence of the judges, parties and accused are required.

Online hearing seems to have a planned future in Malaysia as several regional supreme courts were allowed to adopt online hearing permanently when necessary. The Chief Registrar Office of the Federal Court in Malaysia announced on the 12th of June 2020, that the Court of Appeal and Federal Court in Sabah and Sarawak would be adopting online hearings. During the online hearing, a panel of judges will preside in the Palace of Justice based in Peninsular Malaysia, while the lawyers will conduct their cases in the respective courthouses in Sabah and Sarawak determined by the court registrar. ${ }^{100}$ For criminal cases, the accused will be brought to the nearest courthouse with the Deputy Public Prosecutor. On the other hand, the lawyers conducting civil cases may appear before the panel of judges from their respective offices with the necessary permissions from the panel concerned. The pandemic has accelerated the adoption of technology by the courts and the legal profession in Malaysia. While there were some hiccups in the initial stages, the use of technology assures a wider access to court and an effective delivery of justice to the litigants.

\section{CONCLUSION}

"A virus can have more powerful consequences than any terrorist action"

- Tedros Adhanom Ghebreyesus, The Director-general of the World Health Organization

The unprecedented occurrence of the COVID-19 pandemic slowed down the pace, and in some cases, halted the functioning of sectors worldwide. This is because, even though the most recent pandemic occurred approximately a decade ago, the world was not fully prepared for a pandemic such as this. The resulting suspension in operations allowed courts to develop substitute methods of functioning, focusing on essential functions of the courts and how these functions could be continued outside standard methods of practice. The post pandemic era is not going to be the same as it was before the pandemic. Considering the impact of the pandemic in almost all of the industrial sectors, politics, economic, health and even social lifestyle and livelihoods, certain changes can be expected. Developments in technology have helped companies and even education institutions to transition into a virtual platform that is more convenient and also helps to control the spread of the virus. Governments have invested and adopted certain new methods to ensure the continuation of education as well as to encourage offices to hold meetings remotely. Depending on certain government provisions the Judiciary has been allowed to hold remote hearings for

\footnotetext{
${ }^{100}$ Ida Lim, Amid Covid-19 pandemic, Federal Court trials hearings by video to ensure justice continues (November 2020) < https://www.malaymail.com/news/malaysia/2020/11/09/amid-covid-19pandemic-federal-court-trials-hearings-by-video-to-ensure-jus/1920940 >
} 
relevant cases in order to ensure a continued access to justice through innovative methodologies adopted in accordance with new safety measures. These new methods of operation and the speed with which they have been incorporated into the system has enabled a somewhat smooth transition into what now seems to be the 'new norm' of functioning. As is expected, the novel methods of conducting court operations have their advantages and disadvantages which have to be dealt with when needed. However, the ease with which impacts of the virus have been tackled, especially in the judicial sector, is ample evidence that justice can always be accessed through the applicable means. 